\title{
Standaarde vir Prestasiebeoordeling van Akademiese Personeel aan 'n Verplegingskollege
}

\section{Standards for performance appriasal of academic staff at a nursing college.}

\author{
H Aucamp \\ (M.Cur. RAU) \\ Magisterstudent (Verpleegkunde) \\ RAU \\ \& \\ Marie Muller \\ (D.Cur. RAU.) \\ Professor Verpleegkunde \\ RAU
}

\section{Summary}

A qualitative research strategy was used, within the context of nursing colleges in Gauteng, to formulate standards for performance appraisal of academic staff in a nursing college. The job descriptions of the academic staff (Chief Professional Nurse) were requested from the eight nursing colleges in Gauteng. Only four job descriptions were received. On completion of a document/content analysis of these job descriptions, the following categories were identified: educational responsibilities, student support, professional academic development, academic planning en development and professional services to the community. Four focus groups were held within the selected nursing colleges, based on the principles as described by Krueger (1994) to ascertain their expectations in relation to performance appraisals. These expectations were classified into three main groups: organisational climate, the purpose and process of performance appraisal. Some negative emotional experiences were also listed. These results were exposed to a literature control and resulted in the final conceptual framework for the standards, as reflected in figure one. A total of eleven standards were formulated and exposed to validation in a follow up debate with selected members from the focus groups. The standards relate to the following: a written performance appraisal system reflecting the organisational, process and outcome dimensions; the development of this programme in consultation with the staff; performance appraisal performed within the context of the nursing colleges; written role clarification and expectations of the role-players; the frequency of performance appraisal; the utilisation of both qualitative and quantitative strategies during performance appraisal; a variation of performance appraisal strategies; a feedback and remedial action system to facilitate optimal personal and professional development; protection of the fundamental human rights of the staff during and after performance appraisal and finally the evaluation of the performance appraisal programme. It is recommended that these standards be exposed to testing and further validation.

\section{Abstract}

The purpose with this research is to formulate standards for performance appraisal of academic staff within a nursing college. A qualitative exloratory and descriptive research strategy was utilised, within the context of Gauteng nursing colleges. The conceptual framework on which the standards are based, was developed by exploring and describing existing job descriptions of academic staff (Chief Professional Nurse) employed in nursing colleges, as well as the expectations of academic staff regarding performance appraisal in the college. These results were exposed to a literature control prior to the writing of final statements and a conceptual framework for the formulation of these standards. The standards are divided into three main dimensions, viz. the organisational climate within the nursing college, the purpose of performance appraisal and finally the process of performance appraisal. It is recommended that these standards be implemented in nursing colleges and exposed to further validity studies.

\section{Uittreksel}

Die doel met hierdie studie is die formulering van standaarde vir prestasiebeoordeling van akademiese personeel aan ' $n$ verplegingskollege. 'n Kwalitatiewe verkennende en beskrywende navorsingsontwerp is gevolg, binne die konteks van verplegingskolleges in Gauteng. Die konseptuele raamwerk waarop die standaarde gebaseer is, is ontwikkel deur die verkenning en beskrwying van bestaande posbeskrywings vir akademiese personeel (Hoofverpleegkundige) werksaam in die verplegingskolleges, asook die verwagtinge van dosente oor prestasiebeoordeling in die kollege. Hierdie resualtate is aan ' $n$ literatuurkontrole onderwerp alvorens die finale stellings beskryf is en ' $n$ konseptuele raamwerk vir die formulering van standaarde ontwikkel is. Die standaarde is verdeel in drie hoofdimensies, naamlik die organisasieklimaat in die verplegingskollege, die doel van prestasiebeoordeling en die proses van prestasiebeoordeling. Daar word aanbeveel dat die standaarde geimplementeer word en aan verdere geldigheidstudies onderwerp word. 


\section{Inleiding}

Prestasiebeoordeling van akademiese personeel aan ' $n$ verplegingskollege is 'n gestruktureerde proses waarvolgens die dosent se werkverrigting beoordeel word. Hierdie beoordeling behoort vertrouenswaardig te wees om die werklike standaard van werkverwante gedrag en uitsette deur die dosent (Hootverpleegkundige) te evalueer. Die doel met prestasiebeoordeling is om doelwitbereiking deur die topbestuur van die verplegingskollege te fasiliteer, naamlik hoë gehalte-verpleegonderwys met die opleiding van ' $n$ beroepsparate verplegingspraktisyn op die mees kosteeffektiewe wyse, asook hoë gehalte-personeelbestuur in die kollege wat lei tot optimale persoonlike en professionele ontwikkeling van personeel en ontplooiing van hul potensiaal, optimale funksionering/produktiwiteit, asook 'n hoë graad van werkstevredenheid by die dosent. Prestasiebeoordeling van die dosent (Hoofverpleegkundige) werksaam in ' $n$ verplegingskollege in Suid-Afrika word tans binne die raamwerk van provinsiale gesondheidsdienste se stelsel uitgevoer.

Alhoewel daar nog nie formele navorsing oor die dosent se belewenis van hierdie prestasiebeoordeling gedoen is nie, was daar insidente van arbeidsonrus onder die dosente met griewe oor hierdie bestaande stelsel van evaluering en die geldigheid en betroubaarheid van hierdie evaluering word bevraagteken. Die formulering van standaarde vir prestasiebeoordeling van akademiese personeel aan ' $n$ verplegingskollege behoort die basis te vorm vir vertrouenswaardige evaluering van die dosent se werkverwante doelwitbereiking, gedrag en uitsette, met die fasilitering van gehalte-verpleegonderwys in die kollege en tevredenheid met die prestasiebeoordelingsprogram. Die volgende navorsingsvrae is tersaaklik: wat behoort die inhoud van hierdie standaarde te wees en hoe behoort prestasiebeoordeling uitgevoer te word? Wat is die bestaande posverantwoordelikhede van die akademiese personeel en wat is hul verwagtinge omtrent prestasiebeoordeling?

Die doel met hierdie navorsing is om standaarde te formuleer vir prestasiebeoordeling van akademiese personeel aan 'n verplegingskollege. Hierdie doelstelling is verantwoord deur die volgende voorafgaande doelwitte:

- $\quad$ 'n verkenning en beskrywing van die bestaande posbeskrywings van akademiese personeel aan verplegingskolleges in Gauteng;

- $\quad$ 'n verkenning en beskrywing van akademiese personeel aan verplegingskolleges in Gauteng se verwagtinge ten opsigte van prestasiebeoordeling.

Hierdie artikel fokus hoofsaaklik op die oorhoofse doelwit, naamlik die beskrywing van standaarde vir prestasiebeoordeling van akademiese personeel aan ' $n$ verplegingskollege. Die ontwikkeling van die finale konseptuele raamwerk vir prestasiebeoordeling van akademiese personeel aan ' $n$ verplegingskollege, word met ' $n$ kort opsomming van die voorafgaande resultate (posbeskrywings en verwagtinge) verantwoord.

\section{Terminologie}

\section{Standaard}

'n Standaard is ' $n$ geskrewe verklaring van die verwagte aard/ inhoud en proses van prestasiebeoordeling van akademiese personeel aan 'n verplegingskollege, en bevat meetbare kriteria.

\section{Prestasiebeoordeling}

Prestasiebeoordeling is die sistematiese evaluering van die werkverwante gedrag en uitsette van akademiese personeel aan ' $n$ Verplegingskollege om persoonlike en professionele ontwikkeling van dosente en doelwitbereiking deur die kollege te fasiliteer.

\section{Akademiese personeel}

Akademiese personeel verwys na die voltydse en permanente personeel wat verantwoordelik is vir die onderwysfunksies aan verplegingskolleges en binne die konteks van die Provinsiale postestruktuur as Hoofverpleegkundiges aangestel is.

\section{Verplegingskollege}

' $n$ Verplegingskollege is ' $n$ tersiêre onderwysinstelling wat as missie het die opleiding van verpleegkundiges om in die gesondheidsbehoeftes van die gemeenskap te voorsien. Volgens die Suid-Afrikaanse Raad op Verpleging is ' $n$ verplegingskollege ' $n$ na-sekondêre onderwysinstelling wat professionele verpleegopleiding op 'n basiese en na-basiese vlak aanbied waar sodanige verpleegopleiding goedgekeur is (Suid-Afrikaanse Raad op Verpleging, 1988:1).

\section{Navorsingsontwerp}

'n Verkennende, beskrywende navorsingstrategie met ' $n$ kwalitatiewe oriëntasie binne die konteks van verplegingskolleges in Gauteng, is nagevolg. Die studie is in verskeie fases uitgevoer. In fase een is die bestaande posbeskrywings van akademiese personeel (Hoofverpleegkundiges) verbonde aan verplegingskolleges in Gauteng verken en beskryf. Nadat die posbeskrywings ingesamel is, is 'n dokumentanalise uitgevoer aan die hand van Tesch (in Cresswell, 1994:153) se beginsels van inhoudsontleding. Stellings is geformuleer as basis van die voorlopige konseptuele raamwerk vir die posverantwoordelikhede van die dosent (Hoofverpleegkundige) werksaam in verplegingskolleges. In fase twee is die akademiese personeel (Hootverpleegkundiges) se verwagtinge ten opsigte van prestasiebeoordeling deur middel van fokusgroeponderhoude volgens Krueger (1994:232) se beginsels uitgevoer. Die volgende vrae is tydens die onderhoudvoering gestel: "Wat is u verwagtinge ten opsigte van prestasiebeoordeling in hierdie verplegingskollege?" Die onderhoude is vervolgens verbatim getranskribeer, gevolg deur ' $n$ inhoudsontleding, weereens gebaseer op Tesch se beginsels. Die finale resultate is deur twee onafhanklike navorsers/kodeerders gekontroleer en konsensus is tydens 'n kritiese bespreking/debatvoering bereik. Hierdie resultate is aan ' $n$ literatuurkontrole (fase drie) onderwerp alvorens finale stellings gederiveer is om as basis vir die finale konseptuele raamwerk te dien waarop die standaarde en prestasiebeoordelingsprogram (fase vier) gebaseer is.

Die standaarde voldoen dus aan inhoudsgeldigheid (ontwikkelingsfase). Om eienaarskap vir die aanvaarding en implementering van die standaarde te verhoog, is ' $n$ debatvoeringsessie gehou met agt geselekteerde deelnemers (twee uit elke kollege) wat aan die vier fokusgroeponderhoude deelgeneem het. Die standaarcie is almal aanvaar sonder enige voorgestelde wysigings. 'n Persepsie-opname is nie met die rolspelers uitgevoer nadat die standaarde ontwikkel is om verdere inhoudsgeldigheid by wyse van die kwantifisering van ' $n$ inhoudsgeldigheidsindeks, te bepaal nie.

\section{Populasie en steekproeftrekking}

Die studie is uitgevoer in Gauteng met 'n populasie van agt verplegingskolleges. Die steekproef is doelbewus uitgevoer om vier verplegingskolleges in Johannesburg en Pretoria te betrek, wat verteenwoordigend is van die kultuur- en taalgroepe. Die samestelling van die personeel- en 
studenteprofiel is tradisioneel Afrikaanse blanke, Engelse blanke, Afrikaanse/Engelse Kleurling- en Engelse swartpersoneel/studente. 'n Totaal van 220 dosente (Hoofverpieegkundiges) is werksaam in hierdie vier kolleges. Die volgende insluitingskriteria is vir deelname aan die fokusonderhoudvoering gestel:

- die verplegingskollege beskik oor skriftelike posbeskrywings vir die Hoofverpleegkundiges (akademiese personeel);

- die akademiese personeellid wat aan die onderhoudvoering deelneem is aangestel in ' $n$ Hoofverpleegkundige pos vir minstens twee jaar;

- $\quad$ die deelnemer aan die onderhoudvoering is blootgestel aan (beskik oor ervaring in) prestasiebeoordeling die afgelope twee jaar.

Vir die versameling van posbeskrywings is al agt die verplegingskolleges betrek en die prinsipale (Verpleegdiensbestuurder) is skriftelik versoek om ' $n$ voorbeeld van die Hoofverpleegkundige se posbeskrywing aan die navorser te voorsien. Slegs vier verplegingskolleges het posbeskrywings ingedien, verteenwoordigend van die kultuur- en taalgroep soos uiteengesit in die beskrywing van die populasie. ' $n$ Doelbewuste steekproef is derhalwe gebruik om vier kolleges te identifiseer om verteenwoordiging van die kultuur-en taalgroepe te verseker. Nadat die topbestuur van elke verplegingskollege toestemming vir die navorsing verleen het, is ' $n$ tussenganger in elke kollege genader om met die steekproeftrekking behulpsaam te wees. Tien Hoofverpleegkundiges in elke kollege, wat beskikbaar sou wees op die dag van onderhoudvoering, is op 'n ewekansige wyse (alfabetiese volgorde van name) geselekteer, gebaseer op die beginsel van ingeligte toestemming en vrywillige deelname. Die groepgrootte is beperk tot tien volgens Krueger (1994) se riglyne. Op die dag van onderhoudvoering is die name getrek totdat tien lede ingestem het.

Vir die debatvoeringsessie oor die validering van die standaarde, is agt deelnemers doelbewus geselekteer: twee uit elke groep wat aan die fokusgroeponderhoudvoering deelgeneem het. Hierdie groep was verteenwoordigend van die kultuur- en taalgroepe.

\section{Vertrouenswaardigheid}

Vertrouenswaardigheid van die resultate is verseker deur die benutting van Guba (in Krefting, 1991:214-222) se beginsels en strategieë ten opsigte van geloofwaardigheid, oordragbaarheid, vertroubaarheid en bevestigbaarheid. Die volgende maatreëls is toegepas:

- $\quad$ verlengede betrokkenheid deur die navorser wat vertroud is met die dinamika van 'n verplegingskollege (negentien jaar) en as lid van topbestuur vir agt jaar gefunksioneer het;

- $\quad$ verlengede betrokkenheid tydens die ontleding en verwerking van die data is ook bydraend tot die geloofwaardigheid van resultate;

- die navorser beskik oor 'n na-basiese graad in Verpleegkunde met Verplegingsbestuur as een van die hoofvakke wat vertroudheid met die beginsels van prestasiebeoordeling bevestig;

- $\quad$ triangulering deur die benutting van verskeie databronne, naamlik bestaande posbeskrywings, akademiese personeel (Hoofverpleegkundiges) tydens onderhoudvoering en literatuur vir teoretiese kontrole-doeleindes, asook ' $n$ finale debatvoeringsessie om die inhoudsgeldigheid van die standaarde te bevestig; lidkontrole deur die benutting van twee onafhanklike navorsers/kodeerders tydens die inhoudsontleding van die posbeskrywings en getranskribeerde onderhoude met konsensusbesluitneming oor die kategorieë en sub-kategorieë;

- deelnemerkontrole is ook uitgevoer in die eerste twee fases waar die navorser telkens die resultate aan ' $n$ groep deelnemers voorgelê het vir evaluering;

- alle ontledings (roudata) is vir ouditeringsdoeleindes geberg;

- uitklaring van die navorser en onderhoudvoerder se rolle;

- $\quad$ volledige en digtheidsbeskrywing van die navorsingsprosedure;

- $\quad$ voldoende beskrywing van data met direkte aanhalings ter bevestiging van interpretasies deur die navorsers; die benutting van denkstrategieë om inferensiële inhoudsgeldigheid van die standaarde te bevestig.

\section{Etiese oorwegings}

Toestemming vir die navorsing is vanaf die provinsiale owerhede verkry, asook van die prinsipale (Verpleegdiensbestuurder) van elke verplegingskollege in Gauteng $(\mathrm{N}=8)$. Voorts is die beginsel van ingeligte toestemming van individuele deelnemers toegepas, asook die beginsel van vrywillige deelname en opsie om aan die navorsing te onttrek ten tye van die onderhoudvoering en debatvoeringsessie oor die standaarde. Die algemene beginsels van vertroulikheid is bevestig. ' $n$ Afskrif van die navorsingsverslag is aan die topbestuur van die verplegingskolleges en aan die provinsiale departement van gesondheid voorgehou.

\section{Resultate}

Slegs 'n oorsigtelike beskrywing word gegee van die resultate oor die posbeskrywings en verwagtinge (ingesamel deur middel van fokusgroeponderhoudvoering), om die ontwikkeling van die finale konseptuele raamwerk vir die standaarde te verantwoord. Die finale konseptuele raamwerk word visueel voorgestel (sien figuur een).

\section{Ontleding van bestaande posbeskrywings $(\mathbf{N}=4)$}

Slegs vier van die verplegingskolleges het hul posbeskrywings vir ontleding voorsien. Dit blyk dat sommige kolleges nie oor 'n skriftelike posbeskrywing van die Hoofverpleegkundige werksaam in verplegingskolleges beskik nie, maar benut die gesondheidsdienste se posbeskrywing van die kliniese Hoofverpleegkundige wat uiteraard ongeldig is. Die primêre verantwoordelikhede van die dosent (akademiese personeellid: Hoofverpleegkundige) behels die volgende: onderrigverantwoordelikhede, studentondersteuning, organisatoriese bestuur, professionele akademiese ontwikkeling, akademiese beplanning en ontwikkeling, asook die lewering van professionele dienste aan die gemeenskap. Hierdie resultate word in tabel een as die voorlopige konseptuele raamwerk weergegee. Barker, Cameron en McNulty (1980:121) ondersteun hierdie indeling as die vernaamste elemente van professionele profielareas van onderwyspersoneel. Die algemene onderrigverantwoordelikhede omsluit die teoretiese en kliniese begeleiding, die bestuur van teoretiese en kliniese onderrig en studentevaluering. Studentondersteuning is in al vier die posbeskrywings vermeld, met begrippe soos begeleiding en berading van studente en studentoriëntering. Organisatoriese bestuur is in die 
posbeskrywings uitgelig as die verskillende komitee-aktiwiteite van die personeel, die lewering van insette ten opsigte van die kollegebeleid, kollegiale ondersteuning en kommunikasie deur skriftelike rapportering/verslagskrywing. Professionele akademiese ontwikkeling is in die posbeskrywings uitgelig as 'n verantwoordelikheid van die dosent self, met die inisiëring van personeelontwikkeling en navorsing, asook ' $n$ verbintenis en aktiewe deelname tot persoonlike en professionele groei. Akademiese beplanning en ontwikkeling het sterk in die posbeskrywings gefigureer, met die klem op kurrikulumontwikkeling, die monitering van onderrigprogramme en die formele proses van kommunikasie in die onderskeie onderrigdokumente.

\section{Tabel 1 : Voorlopige konseptuele raamwerk vir prestasiebeoordeling : posverantwoordelikhede van akademiese personeel aan verplegingskolleges}

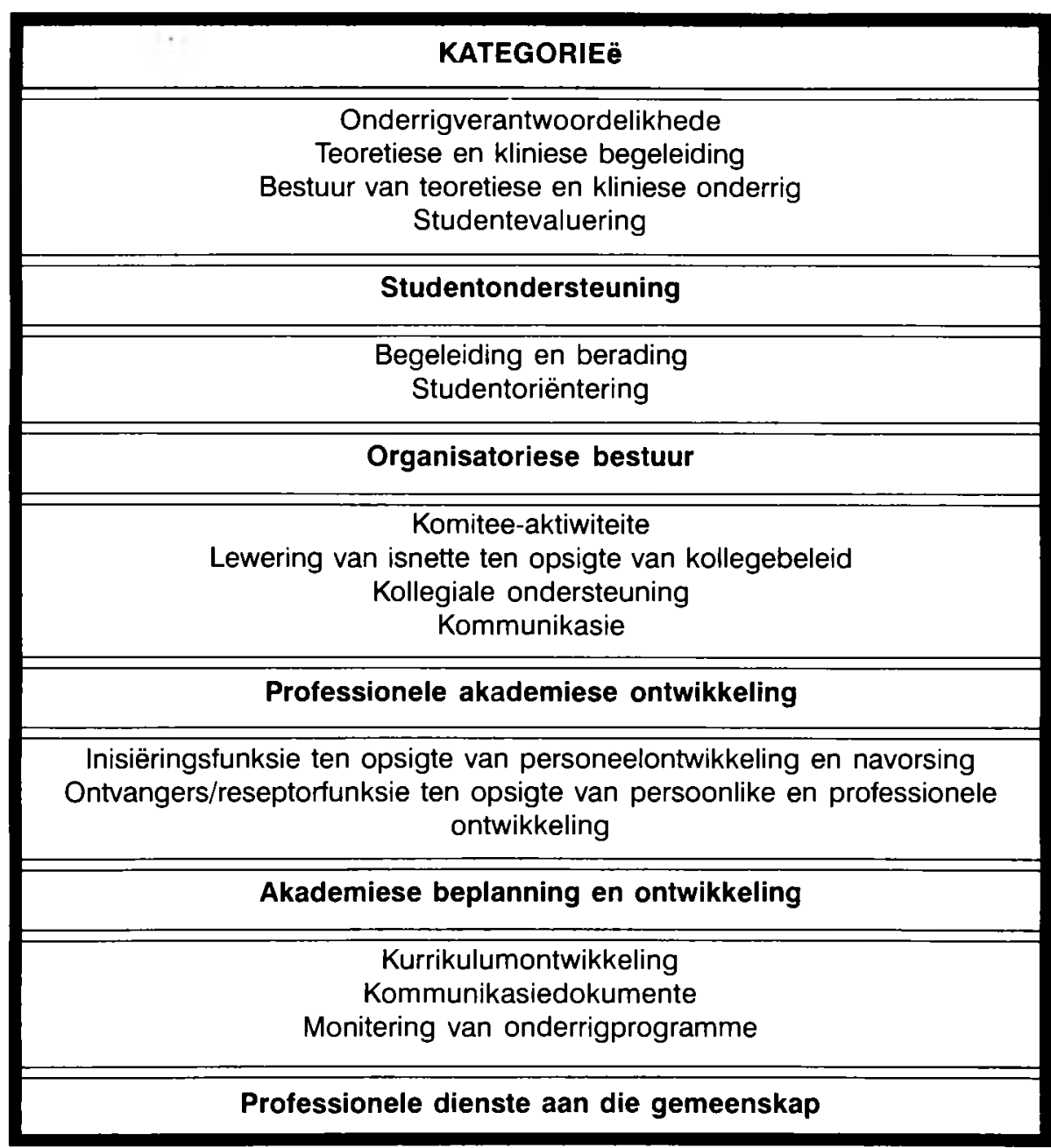

van insette in die formulering van kollegebeleid, kollegiale ondersteuning en toepaslike kommunikasie in die verplegingskollege;

- $\quad$ professionele en akademiese ontwikkeling met die inisiëring van persoonlike en professionele ontwikkeling in navorsing en preseptorfunksie;

- $\quad$ akademiese beplanning en ontwikkeling met die fokus op kurrikulumontwikkeling, kommunikasie en monitering van onderrigprogramme;

- die lewering van toepaslike professionele dienste aan die gemeenskap.

Die verwagtinge van die dosent ten opsigte van prestasiebeoordeling aan 'n verplegingskollege.

Fokusgroeponderhoude $(\mathrm{N}=4)$ is met tien deelnemers in elk van die vier verplegingskolleges gevoer. Die volgende hoofkategoriee is geidentifiseer: organisasieklimaat, doel van prestasiebeoordeling, proses van prestasiebeoordeling en emosies. Hierdie resultate is in die vorm van ' $n$ verfynde konseptuele raamwerk opgestel (vergelyk tabel twee).

Die konteks van die verplegingskollege word in die organisasieklimaat uitgebeeld. ' $n$ Sterk verwagting om ' $n$ heelpersoonbenadering tydens prestasiebeoordeling te volg, is gestel: "Dit sal beter wees om te fokus op die heelpersoon en nie net op die werk wat jy doen nie"; For me the thing is to look at the person in total"; "Die persoon moet in totaliteit gesien word - ons is nie net werkesels nie maar sosiale en emosionele wesens ook"; "Die evaluering moet ook meer individualisties wees - fokus op die persoon in geheel." Loder (1990:50) bevestig die belangrikheid dat prestasiebeoordeling ook al die behoeftes van die persoon wat evalueer word, in ag moet neem. Baker (1996:31) beklemtoon dat die sukses van prestasiebeoordeling van die holistiese benadering afhanklik is.

Die organisasieklimaat word voorts in die visie/missiestelling, die filosofie, beleid/ prosedures, die bestuurstyl en kollegiale ondersteuning gereflekteer. Die organisasieklimaat kan dus die akademiese personeel se funksionering en derhalwe die prestasiebeoordeling positief of negatief beinvloed. Hierdie verwagting word deur Mohrman et al. (1990) en Malan en Roos (1991:222) bevestig. Die organisasieklimaat rig die proses van prestasiebeoordeling en deelnemers vanuit al die fokusgroepe was van mening dat prestasiebeoordeling kongruent moet wees met die visie, missie en filosofie van die organisasie en dat elke personeellid vertroud moet wees met die inhoud daarvan. Die beginsels en proses van prestasiebeoordeling behoort skriftelik aan almal voorsien te word: "Die strategie en proses moet in lyn wees met die filosofie van die organisasie en almal moet weet wat dit behels - daar moet geen verrassings wees nie." Spangenberg (1994:43) beklemtoon die belang van deursigtigheid en dat die missie en beleid van die organisasie riggtinggewend vir prestasiebeoordeling behoort te wees. 


\section{Tabel 2: Verfynde konseptuele raamwerk: verwagtinge van personeel}

\begin{tabular}{|c|c|}
\hline & VERWAGTINGE VAN AKADEMIESE PERSONEEL \\
\hline 1. & $\begin{array}{l}\text { Organisasieklimaat } \\
\text { Heelpersoonbenadering; organisatoriese filosofie, behoeftes en beleid; bestuurstyl/postestruktuur; werkkonteks; } \\
\text { kollegiale ondersteuning; stresfaktore. }\end{array}$ \\
\hline 2. & $\begin{array}{l}\text { Doel met prestasiebeoordeling } \\
\text { * } \quad \text { Personeelvoorsiening/personeelbenutting; plasing; werksladingverspreiding } \\
\text { * Personeelontwikkeling; persoonlike en professionele ontwikkeling; leierskapsontwikkeling (kennis, } \\
\text { kommunikasievaardighede, rolmodellering) } \\
\text { * Personeelbehoud: motivering/erkenning; bevordering; professionaliteit } \\
\text { * } \quad \text { Personeelbesoldiging/finansiële erkenning }\end{array}$ \\
\hline 3. & $\begin{array}{l}\text { Proses van prestasiebeoordeling } \\
\text { * Stel van standaarde en kriteria: posbeskrywing/taakmanifeste; interne en eksterne kollegebetrokkenheid } \\
\text { * } \quad \text { Proses van beoordeling: frekwensie van beoordeling; rolspelers (portuurgroepevaluering, evalueerder se } \\
\text { evaluering, studentevaluering, selfevaluering); instrument; evalueerder se verantwoordelikhede; } \\
\text { evalueringstrategieë (kritiese insidente); kwalitatiewe benadering; remediëring (terugvoering) }\end{array}$ \\
\hline 4. & $\begin{array}{l}\text { Emosionele belewenisse } \\
\star \quad \text { Woede, ontnugtering }\end{array}$ \\
\hline
\end{tabular}

Die doel met prestasiebeoordeling is ' $n$ belangrike aspek wat in al die fokusonderhoude beklemtoon is. Tans ervaar personeel prestasiebeoordeling as 'n burokratiese proses wat deur hoofkantoor afgedwing word en nie positief aangewend word nie. Dit behoort as basis gebruik te word vir die persoonlike en professionele ontwikkeling van personeel en vir bestuursbesluite. "Ons moet ons eie instrument hê sodat ons die regte dinge kan meet en regstel - ons behoort daardeur te groei;" "Dit is nie gemaak vir "n dosent nie - dit is vir die beampte wat die penne en 'sharpeners' moet uitgee." Die proses van prestasiebeoordeling behoort wetenskaplikgefundeerd, buigsaam en deursigtig te wees. Hierdie beginsel het sterk na vore gekom as ' $n$ verwagting: "Die huidige evalueringstelsel kom van die staatsdiens af en het niks met klasgee te make nie - daar moet 'n stelsel vir ons wees wat wetenskaplik uitgewerk is en almal moet weet wat dit behels. Verder is elke onderrigsituasie anders en die evaluering moet voorsiening maak hiervoor." Die doel, wetenskaplike en etiese beginsels van prestasiebeoordeling word in die literatuur bevestig. 'n Sikliese proses word beklemtoon met die stel van standaarde, evaluering van werkverrigting aan die hand van hierdie standaarde, met tydige en toepaslike remediëring om die doelwitbereiking te fasiliteer (Gien, 1991; Gmelch, 1993; Loder, 1990; Stufflebeam, 1988). Prestasiebeoordeling is ' $n$ dinamiese proses en behoort gebaseer te wees op die posverantwoordelikhede van die akademiese personeel in die verplegingskollege. "A spirit of dynanism in the life of an organization gives vitality to the appraisal program." Hierdie stelling is in 1977 deur Smith en Brouwer (1977:58) gemaak en beklemtoon die belangrikheid van prestasiebeoordeling in 'n organisasie.

Die deelnemers het etlike negatiewe ervaringe en emosies oor prestasiebeoordeling in die verplegingskolleges uitgelig. Daar was intense ontnugtering oor die ongeldigheid van die stelsel wat gelei het tot negatiewe emosies soos woede: "Prestasiebeoordeling is eintlik ' $n$ klomp seer gevoelens wat naderhand verwerk moet word"; "It has no purpose - lots of paperwork; an academic tool; a professional exercise which has to be carried out"; "Ek dink die huidige stelsel is "n klug my voete was skoon onder my uitgeslaan"; "Dit wek by ons almal negatiewe gevoelens - ons is kwaad oor die hele storie." Nadat " $n$ literatuurkontrole uitgevoer is, is die volgende dimensies van prestasiebeoordeling bygevoeg: streshanteringsmeganismes, beoordeling in spanverband, vertroulikheid en deursigtigheid, doelwitkontraksluiting, onderrigportefeulje, appellering, opvolgaksies, asook programevaluering wat monitering en ouditering insluit. Finale stellings vir prestasiebeoordeling van akademiese personeel aan ' $n$ verplegingskollege word soos volg gestel:

- $\quad$ prestasiebeoordeling is ' $n$ gestruktureerde program, bestaande uit die organisasieklimaat, die doel van prestasiebeoordeling en die proses van prestasiebeoordeling;

- die organisasieklimaat bevat en omskryf bestuursaspekte omtrent die organisasie, die dosent as individu en die evalueerder tydens prestasiebeoordeling;

- $\quad$ prestasiebeoordeling is ' $n$ gestruktureerde proses bestaande uit die stel van standaarde, die proses van beoordeling en remediëring, met deurlopende konstruktiewe terugvoering;

- die doel van prestasiebeoordeling is persoonlike en professionele ontwikkeling van die akademiese personeellid en dien as basis vir bestuursbesluitneming in die verplegingskollege;

- $\quad$ prestasiebeoordeling fasiliteer gehalte-onderwys, gehalte-personeelbestuur en arbeidsvrede (ten opsgite van prestasiebeoordeling) in die verplegingskollege.

Die finale konseptuele raamwerk waarop die standaarde vir prestasiebeoordeling gebaseer is, word in figuur een visueel voorgestel. 'n Stelselbenadering word gevolg met die insette wat deur die organisasieklimaat verteenwoordig word. Prestasiebeoordeling word gerig deur die bestuursdimensies van die organisasie self, met die individu wat beoordeel word en die prestasiebeoordelaar(s). Die organisatoriese insette word in die verplegingskollege se visie- en missiestelling gereflekteer, met 'n toepaslike bestuurstyl wat fasiliterend vir prestasiebeoordeling is. Dit is belangrik om ' $n$ heelpersoonbenadering te volg, binne 'n konteks wat bevorderlik vir prestasiebeoordeling is, met die klem op kollegiale ondersteuning binne spanverband en die hantering en erkenning van stressors in die werkplek. Voorts is dit nodig dat die evalueerder op leierskapsontwikkeling fokus en die 
verantwoordelikhede uitvoer om doelbereiking te fasiliteer.

Die proses van prestasiebeoordeling is gebaseer op standaarde vir prestasiebeoordeling, gevolg deur die proses van beoordeling met toepaslike en tydige remediëring wat met konstruktiewe terugvoering gepaard gaan. Die proses van prestasiebeoordeling fokus dus op die stel van standaarde wat die aard en inhoud van prestasiebeoordeling omsluit, asook op die administratiewe proses waar aspekte soos die frekwensie van beocrdeling, die rolspelers wat betrokke is, die tipe instrument wat gebruik word, asook die benutting van beide kwalitatiewe en kwantitatiewe evalueringstrategieë, insluit. Die derde dimensie van prestasiebeoordeling fokus op die toepaslike remediëring met konstruktiewe terugvoering en opvolgaksies, ten einde persoonlike en professionele ontwikkeling van die akademiese personeellid te fasiliteer. Dit is ook belangrik om die fundamentele regte van die individu ten opsigte van appellering te beskerm. Die uitkoms van prestasiebeoordeling behoort ook konstruktief deur die bestuurder aangewend te word as basis vir bestuursbesluitneming in die benutting/aanwending van personeel. Die uitsette van prestasiebeoordeling is gerig op gehalte-onderwys, gehalte-personeelbestuur en arbeidsvrede in die verplegingskollege. Dit is egter ook belangrik om die program van prestasiebeoordeling gereeld te evalueer (Aldrich, 1997; Andrusyszyn, 1990:410-412; Bagwandeen, 1993:95-98; Baker, 1996; Beebe, 1987:96-101; Boland \& Sims, 1996:345-348; Brown \& Ward-Griffin, 1994:299-305; Burke, 1994:194-202; du Plessis, 1990; Gien, 1991:92-94; Murphy \& Cleveland, 1991; Spangenberg 1994; Stufflebeam, 1988).

\section{Standaarde vir prestasiebeoor- deling van akademiese personeel aan 'n verplegingskollege}

1. Daar is ' $n$ geskrewe prestasiebeoordelingsprogram in die verplegingskollege wat die dimensies van organisasieklimaat, proses van prestasiebeoordeling en die gewensde uitsette reflekteer:

- die kontekstuele organisatoriese faktore wat prestasiebeoordeling beïnvioed is uiteengesit

- die proses van prestasiebeoordeling is in die vorm van standaarde (beleid en prosdures) beskryf

- die doel van prestasiebeoordeling en gewensde uitsette (gehalte-aanwysers) is beskryf

2. Die prestasiebeoordelingsprogram is saamgestel in konsultasie met die akademiese personeel van die verplegingskollege:

- wedersydse rolverwagtinge (bestuurslede en akademiese personeellid) met betrekking tot prestasiebeoordeling is uitgeklaar

- daar is bewys van deurlopende deursigtigheid en konsultasie/deelnemende besluitneming in die ontwikkeling en vernuwing van die prestasiebeoordelingstelsel

- die prestasiebeoordelingsprogram word in die oriëntasieprogram van nuwe akademiese personeel aangespreek daar is 'n opleidingstelsel vir alle akademiese personeel en evalueerders om vertrouenswaardige prestasiebeoordeling te fasiliteer

3. Die prestasiebeoordeling vind plaas binne die konteks van die verplegingskollege:

- die prestasiebeoordeling is kongruent met die verplegingskollege se visie en missie-stellings die prestasiebeoordelingsprogram is verenigbaar met ' $n$ deelnemende bestuurstyl ingevolge die beginsels van konsultasie en demokratisering in die werkplek

- die klimaat in die verplegingskollege is bevorderlik vir prestasiebeoordeling met ' $n$ toepaslike kollegiale ondersteuningstelsel

- individuele werkverrigting word binne die konteks van 'n verplegingskollege op ' $n$ holistiese wyse beoordeel die prestasiebeoordelingstelsel is buigsaam om die interne en eksterne stressors (versagtende omstandighede) in ag te neem

- $\quad$ die kontekstuele/versagtende omstandighede word in die prestasiebeoordelingsverslag vermeld

- daar is 'n leierskapsontwikkelingsprogram vir alle rolspelers oor prestasiebeoordeling om positiewe verhoudinge tydens die proses van beoordeling te fasiliteer

die evalueerder se verantwoordelikhede ten opsigte van leierskapsontwikkeling en die proses van prestasiebeoordeling is skriftelik uitgeklaar

- $\quad$ interne en eksterne (buite die verplegingskollege) kollegiale betrokkenheid in die proses van beoordeling word uiteengesit

4. Die prestasiebeoordeling is gebaseer op die skriftelike rolverwagtinge, taakanalise en posbeskrywings van die akademiese personeel in die verplegingskollege en evalueer minstens die volgende:

- die ooreengekome sleutelprestasie-areas

- die gehalte van verpleegonderwys deur die akademiese personeellid

deelname en bydrae in onderrig/komiteeverwante aktiwiteite die gehalte van operasionele bestuur en administratiewe voortreflikheid in verpleegonderwys professionele dienslewering aan die gemeenskap (insluitende beroepsgemeenskap) deelname aan studente-ondersteuningsprogramme professionele ontwikkeling en navorsing professionele gedrag en aanspreeklikheid deur die akademiese personeel in die verplegingskollege Die frekwensie van die prestasiebeoordeling is uiteengesit:

die aard en omvang van deurlopende beoordeling die aard en omvang van finale jaarlikse beoordeling die aard en omvang van langtermyn-meriete beoordeling

6. Die prestasiebeoordelingsprogram maak voorsiening vir beide kwalitatiewe en kwantitatiewe evalueringstrategieë: nie-kwantifiseerbare uitsette word in aggeneem

statisties-verrekenbare uitsette word bepaal

Die prestasiebeoordelingprogram is gebaseer op minstens die volgende evalueringstrategieë: selfevaluering deur die akademiese personeellid onderrigevaluering deur studente portuurgroepevaluering deur die toesighouer(s) en mede-kollegas

evaluering deur lede van topbestuur verifiëring deur lede van hoofkantoor vir merieteuitligtings

Die prestasiebeoordelingsprogram is vertrouens- 


\section{Konseptuele raamwerk: standaarde vir prestasie-beoordeling aan 'n verplegingskollege}

NISASIEKLIMAAT

PRESTASIEBEOORDELINGSPROSES

DOEL VAN PRESTASIEBEOOR
Heelpersoonbena$\mathrm{ng}$

Verkkonteks

ollegiale ondersteunin spanverband tressors \& Stresstering

ierskapsontwikkeling rantwoordelikhede
- Stel van prestasiebeoordelingstandaarde

Vereistes

Taakanalise

Posbeskrywings/

Interne en Eksterne Kollegeale betrokkenheid

- Proses van beoordeling

Frekwensie

Rolspelers

Instrument

Kwalitatiewe en Kwantitatiewe evalueringstrategieë

- Remediëring

Konstruktiewe terugvoering

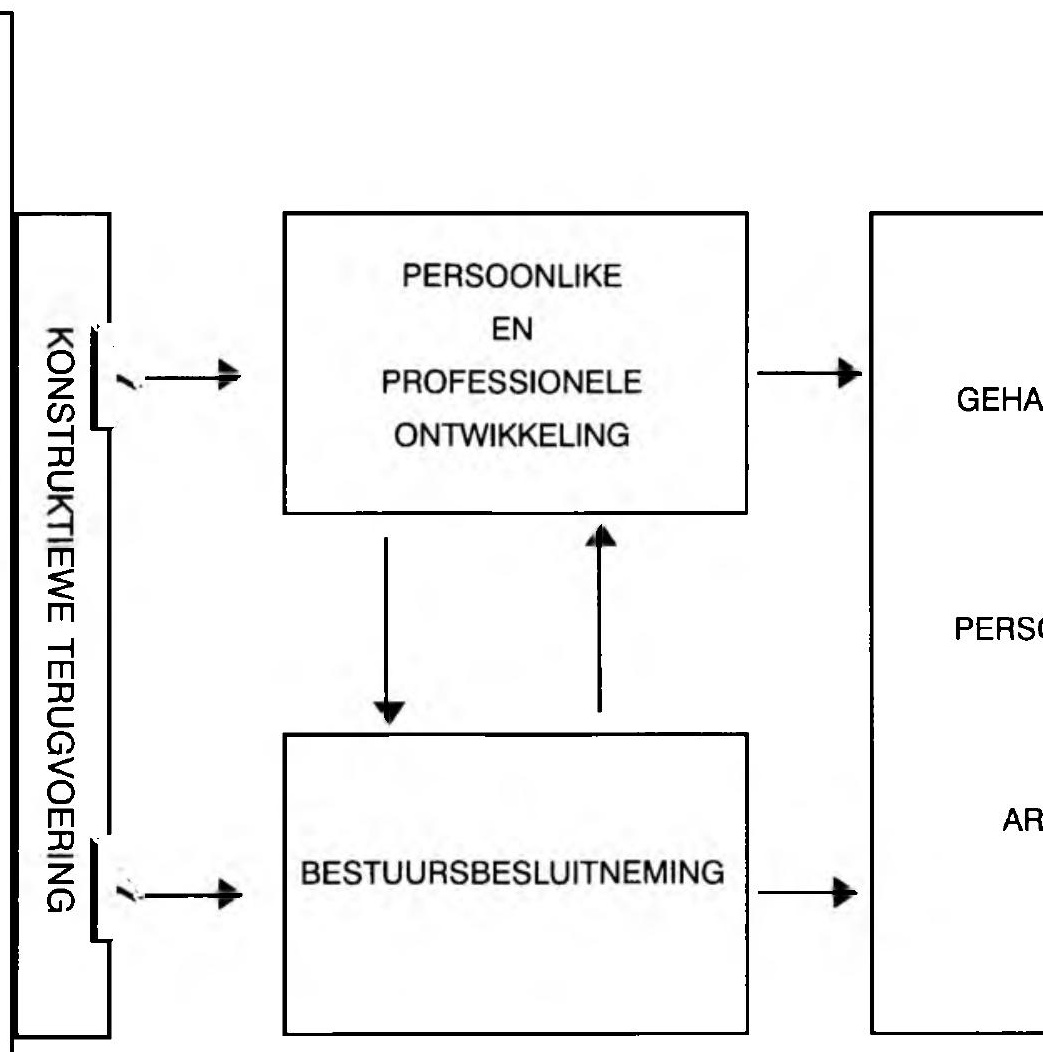
Opvolgaksies Apellering 
waardig:

- die inhoudsgeldigheid van die instrument(e) is verantwoord/bevestig

- die konstrukgeldigheid van die kwantitatiewe instrument(e) is bevestig

- die betroubaarheid van die kwantitatiewe instrument(e) is bevestig

- verifiëringstrategieë word gebruik om kwalitatiewe resultate te bevestig

- inter-beoordelingsbetroubaarheid tussen evalueerders is bevestig

9. Daar is ' $n$ terugvoering- en remediëringstelsel om tekortkominge die hoof te bied en om persoonlike en professionele ontwikkeling by die akademiese personeel te fasiliteer:

- $\quad$ terugvoering geskied op 'n professionele wyse binne 'n klimaat van wedersydse vertroue die prestasiebeoordeling maak voorsiening vir individuele groeipotensiaal

- $\quad$ tydige kontruktiewe en skriftelike terugvoering word deur die toesighouer(s) gegee

- $\quad$ die nodige opvolgaksies vir remediëring word gesamentlik deur die akademiese personeellid en die toesighouer(s)/bestuurslede beplan, onderhandel en gedokumenteer

- $\quad$ die akademiese personeellid lewer ' $n$ bydrae in die beplanning en kontraktering van haar/sy eie persoonlike en professionele ontwikkelingsplan

- $\quad$ persoonlike doelwitte word deur die akademiese personeellid in konsultasie met die toesighouer(s)/ bestuur skriftelik gestel

- $\quad$ daar is ' $n$ meriete-stelsel vir die erkenning van buitengewone prestasie, gebaseer op die resultate van prestasiebeoordeling

- $\quad$ persoonlike en professionele ontwikkeling word gefasiliteer deur die ontplooiing van toepaslike hulpbronne

- daar is ' $n$ streshanteringsmeganisme vir die bestuur van omgewingsfaktore wat ' $n$ negatiewe impak op prestasiebeoordeling het

10. Die fundamentele menseregte van die akademiese personeellid word binne die konteks van prestasiebeoordeling beskerm:

- die beginsels van vertroulikheid/privaatheid word binne die bestuurskonteks nagekom

- daar is ' $n$ stelsel vir appellering deur die akademiese personeellid

- die stelsel van appellering is op skrif gestel

- $\quad$ daar is ' $n$ stelsel om die arbeidsregte van die akademiese personeellid te beskerm

11. Die verplegingskollege het ' $n$ stelsel waarvolgens programevaluering en doelbereiking beoordeel word:

- daar is ' $n$ stelsel waarvolgens die prestasiebeoordelingsprogram ge-evalueer word

- $\quad$ toepaslike vernuwing word aan die hand van die evalueringsresultate ge-aktiveer

- die gehalte van verpleegonderwys in die verplegingskollege word bepaal

- $\quad$ die gehalte van personeelbestuur in die verplegingskollege word bepaal

- die vlak van arbeidsvrede (met betrekking tot die prestasiebeoordelingstelsel) word in die verplegings- kollege bepaal.

\section{Gevolgtrekking}

Standaarde vir prestasiebeoordeling van akademiese personeel aan ' $n$ verplegingskollege is geformuleer vir ' $n$ verplegingskollege in Gauteng. Die standaarde is in drie hoofdimensies verdeel, naamlik organisasieklimaat, die doel van prestasiebeoordeling en die proses van prestasiebeoordeling. Hierdie standaarde dien as basis vir ' $n$ vertrouenswaardige prestasiebeoordelingsprogram in 'n verplegingskollege.

\section{Aanbevelings}

Die volgende aanbevelings word gemaak:

a) die implementering van hierdie standaarde in verplegingskolleges;

b) nasionale validering van hierdie standaarde in al die verplegingskolleges van Suid-Afrika met die kwantifisering van ' $n$ inhoudsgeldigheidsindeks deur middel van 'n persepsie-opname onder die rolspelers;

c) die bepaling van konstrukgeldigheid van die standaarde;

d) die ontwikkeling van 'n evalueringsinstrument gebaseer op die standaarde

e) 'n aanbeveling na die provinsiale dienste vir hersiening van die prestasiebeoordelingstelsel vir akademiese personeel aan verplegingskolleges, gebaseer op hierdie standaarde;

f) die ontwikkeling van ' $n$ model oor prestasiebeoordeling van akademiese personeel aan verplegingskolleges.

\section{Erkenning}

Al die deelnemers tydens hierdie navorsing word bedank vir hul waardevolle insette en bydrae tot die ontwikkeling van standaarde oor prestasiebeoordeling van akademiese personeel aan 'n verplegingskollege. 
ALDRICH, J.W. 1997. Staffing concepts and principles. (In: Tracey, WR ed. 1994: Human resources management and development handbook; second edition. Toronto: Amacom.)

ANDRUSYSZYN, M.A. 1990. Faculty evaluation: a closer look at peer evaluation. Nurse Education Today, 10(5), 1990: 410-414.

BAGWANDEEN, D . 1993. Quality assurance in colleges of education. South African Journal for Higher Education, 7(2) 1993: $95-98$.

BAKER, J. 1996. Causes of failure in performance appraisal and supervision. London: Quorum Books.

BARKER, L.J., CAMERON, B.J., \& McNULTY, L.J. 1980. Staff performance, planning and assessment (Unpublished paper).

BEEBE, R.E. 1987. Developing sound performance appraisal procedures. NASSP Bulletin, 71 (497) March, 1987: 96-101.

BOLAND, D.L., \& SIMS, S.L. 1996. A comprehensive approach to faculty evaluation. Journal of Nursing Education, 27 (8), October, 354-358

BROWN, B., \& WARD-GRIFFIN, C. 1994. The use of peer evaluation in promoting nursing faculty teaching effectiveness: a review of the literature. Nurse Education Today, 14(3), June 1994: 299-305.

BURKE, L.M. 1994. Teacher self-evaluation: an assessment using Delamont's beyond Flanders' fields' technique. Nurse Education Today, 14(3), June 1994:194-202.

COWMAN, S. 1997. The role of formal staff appraisal in nurse education. Nurse Education Today, 13 (1), 1997: 69-74.

CRESSWELL, J.W. 1994. Research design: qualitative and quantitative approach. New Delhi: Sage.

DU PLESSIS, S.J.P. 1990. Onderrigevaluering en die erkenning van uitmuntende onderrig. Suid-Afrikaanse Tydskrif vir Hoër Onderwys, Spesiale Uitgawe, 1990:30-33.

DU TOIT, P.H. 1990. Mikro-onderrig: afskopfase vir dosenteevaluering. Suid-Afrikaanse Tydskrif vir Hoër Onderwys, Spesiale uitgawe, :34-40

GIEN, L.T. 1991. Evaluation of faculty teaching effectiveness towards accountability in education. Journal of Nursing Education, 30(2):92-94, Febr.

GMELCH, W.H. 1993. Coping with faculty stress. New Delhi: Sage.

KRUEGER, L.A. 1994. Focus Groups. A practical guide for applied research; second edition. New Delhi: Sage.

LODER, C. 1990. Quality assurance and accountability in higher education. London: Kogan Page.

MALAN, S.P.T., \& ROOS, D. 1991. Die suksesvolle dosent. (In: Malan SPT \& Du Toit, PHreds. 1991: Suksesvolle onderrig. Pretoria: Academica.)
MOHRMAN, A.M., RESNICK-WEST, S.M., \& LAWLER III, E.E. 1990. Designing performance appraisal systems. Oxford: Jossey-Bass.

MURPHY, K.R., \& CLEVELAND, J.N. 1991. Performance appraisal. Boston: Allyn and Bacon.

SMITH, H.P. , \& BROUWER, P.J. 1977. Performance appraisal and human development. London: Addison-Wesley.

SPANGENBERG, H. 1994. Understanding and implementing performance management. Kenwyn: Juta.

STUFFLEBEAM, D.L. 1988. The personnel evaluation standards: how to assess systems for evaluating educators. London: Sage.

SUID-AFRIKAANSE RAAD OP VERPLEGING. 1988. Goewermentskennisgewing R425, soos gewysig deur R723 van 1988: Regulasie betreffende die goedkeuring van die minumumvereistes vir opleiding en onderrig van 'n Verpleegkundige (Algemene, Psigiatriese en Gemeenskaps) en Vroedvrou wat lei tot registrasie. Pretoria: Staatsdrukker. 